\title{
CRISIS OF MUSLIM CIVILIZATION IN MODERN TIMES: SOME INSIGHTS FROM IBN-E-KHALDUN'S THOUGHTS AND IDEAS
}

\author{
Dr. Faraz Anjum
}

\begin{abstract}
No one would, probably, doubt that Muslim civilization is facing a serious crisis since the 18th century. It first resulted in political chaos and ultimately colonization of Muslim lands by Western powers. Later, Muslim civilization faced serious cultural and intellectual onslaught from the West which intensified and deepened the crisis. Though the period of Western colonization ostensibly came to an end in the middle of the 20th century, Muslim lands did not come out of the crisis. Despite some sincere efforts for Islamic revivalism, Muslim civilization has failed to respond to the modern crisis, particularly 9/11 incident has exposed the vulnerability of the Muslim world to Western political agenda, and its failure to respond effectively to Western civilizational challenges. The scholars are divided as to the cause of this crisis of the Muslim world and consequently, as to the measures to remedy the problem.

Abdur Rehman Ibn Khaldun, a 13th century Muslim historian and intellectual, emerged at a time when the Muslim states in the Maghreb (North Africa) and Muslim Spain were passing through a phase of decline. His critical thoughts on the society (Al-Imran) and particularly his concept of social solidarity (Al-asabiyah), as propounded in his magnum opus, Maqaddimah (Prolegomena to History), can provide important insights into the present crisis of the Muslim Civilization. The present paper seeks to understand and explain this crisis with the help of the social analysis and critical ideas of Ibn Khaldun.
\end{abstract}

Key words: Ibn-e-Kahldun, Historian, Social Solidarity, Muqaddimah, Muslim world, Civilizational Challenges

\section{INTRODUCTION}

Muslim civilization faced a number of challenges soon after the period of Khilafat-i-Rashidah (Pious Caliphate). The first challenge came as a result of its rapid growth, coupled with internal tribal dissensions resulting in the dominance of hostile political factions. Though this challenge resulted in the establishment of autocratic governments, it did not lead to either loss of political dominance of Muslim community or a serious crisis in religious or intellectual thought. The second crisis came with the translations of Greek philosophical texts in the $9^{\text {th }}$ and $10^{\text {th }}$ centuries. It was basically an intellectual crisis in which new philosophical thoughts seriously challenged some of the fundamentals of Islamic principles. However, the ulama (Muslim scholars of religious sciences) were able to counter this challenge and assert the superiority of Islamic principles by introducing a new Ilm-ul-Kalam (scholasticism). The next challenge to Muslim civilization came with the Mongol raids from the East. It destroyed the flourishing Muslim towns in the whole of Middle East and Central Asia and for the time being seriously hampered the cultural and intellectual growth of Muslim civilization and led to the destruction of political authority in major parts of the Muslim world. However, the crisis proved to be short-lived as the barbaric tribes were 
converted to Islam and inaugurated a new verve in the body politic of Islam. The Turks and Mongols, after being converted to Islam, became the harbingers of a new renaissance of Muslim civilization.

It was in the middle of the eighteenth century that the present crisis of Muslim civilization began to manifest itself. Initially, it started with the political decline of centralized empires and their balkanization into petty states and kingdoms. There were diverse and complex administrative, political and socio-cultural reasons behind this decline. This weakening of centralized empires led eventually to the political dominance of European powers as the latter were able to annihilate the small Muslim states, mainly with better tactics of manipulation. Despite having attained independence from the political hold of colonial powers, the Muslim states have largely failed to build their societies and reintegrate the social fabric.

The post-9/11 world has exposed the Muslim civilization to new challenges. It has reinforced the idea of Islam as an enemy of the West and Muslim civilization is being widely viewed as "terrorist," "fundamentalist," and "fanatic." Though this idea is not new, rather a continuation of the previous ideas about Islam; however the major difference is that previously a tiny minority implicitly claimed and now a large segment of Western media and public opinion has openly started to believe that Islam is a predatory civilization threatening, not just the West, rather the whole civilizational progress of mankind. This trend has manifested itself in the symbolic acts of banning of Muslim women's scarfs and disallowing the minarets of mosques. This growing Islamophobia is a new challenge to the already weakened Muslim civilization. It is worthwhile to see whether a $14^{\text {th }}$ century Tunisian scholar can provide a way out of this challenge. However, before delving into his ideas and thoughts, it would be appropriate to briefly examine the life of Ibn Khaldun which in more than one way reminds us of the life history of many modern Muslim intellectuals.

\section{LIFE AND TIMES OF IBN-E-KHALDUN}

Abu Zaid Abdur Rehman Ibn Muhammad Ibn Muhammad Ibn Khaldun was born in Tunis in 1332. The tradition describes that his ancestor Khalid had come with an army to Spain in the $3^{\text {rd }}$ century A.H. His family had lived in Seville in Muslim Spain before moving to Tunis. His early career as public official involved him in politics and power struggles between the Hafsids of Tunis, the Marinids of Fez, and the Nasrids of Granada. Many times he was imprisoned and many times appointed to the highest offices. However, in 1378 he left public life for a four-year sojourn in Tunis (1378-1382), which he devoted to scholarship. It was in this period that he completed his first versions of both the Muqaddimah and his historical work, Kitab-ul-Ibar, although he continued to revise these texts for the remainder of his life. In 1382, he received permission to undertake the pilgrimage. But he did not reach Mecca. For in Cairo, the Mamluk Sultan gave him a professorship at the University of al Azhar, and in 1384 appointed him as Chief Maliki Qazi. In this position, he energetically corrected certain abuses and instituted certain reforms which aroused much opposition. He therefore, had to resign from Qaziship and retired to an estate in 1385. In 1387, he made his pilgrimage to Mecca. After his return to Cairo, he employed his leisure to revise the History and to prepare his autobiography, Al-Tarif, which was completed in 1394,

1 Akbar Ahmed, "Ibn Khaldun's Understanding of Civilizations and the Dilemmas of Islam and the West Today," Middle East Journal, 56, No. 1(Winter, 2002): 23. 
when he was sixty-two. In 1399, he was again appointed as Qazi, but could retain this office for only a year and a half. While in the service of Mamluk Sultan, Ibn Khaldun traveled to Damascus as part of an expedition to counter the invasion of Amir Timur (Tamerlane). Ibn Khaldun met Timur after the latter had taken Damascus, and subsequently wrote a detailed account of his interview. ${ }^{2}$ He returned to Cairo where he died in 1406, shortly after his sixth appointment as Chief Maliki Qazi. ${ }^{3}$

Ibn Khaldun's life may be divided into three parts. The first 20 years were occupied by his childhood and education, the next 23 years by the continuation of his studies and his political adventures, and the last 31 years as a scholar, teacher and Qazi. The first two periods were spent in the Muslim West and the third was divided between the Maghrib and Egypt. ${ }^{4}$ A close look at his life has persuaded one scholar to comment that Ibn Khaldun had his faults and serious blemishes of character as he "easily changed his allegiance, leaving one master to serve another, shrewdly watching their chances of success. He was as versed in intrigue as any diplomat in any other age." However, in all fairness, his career can only be studied in the context of his times. He was certainly living in an age where living had become a dangerous business. Charles Issawi has rightly pointed out that:

There have been few periods in history as agitated, not to say chaotic, as the thirteenth century in North Africa after the collapse of the Al Muwahhidun dynasty. Innumerable kinglets, princelets, and feudal lords struggled for supremacy; towns changed masters with astonishing rapidity; intrigue, murder, and revolts were rife. Survival was as much a question of luck as ability. 6

Notwithstanding his political pursuits, Ibn Khaldun is best known as the author of Muqaddimah (Introduction), the first part of his universal history titled Kitab al-Ibar. ${ }^{7} \mathrm{He}$ has divided his historical work into three large parts: First part deals with society and its inherent phenomena, such as sovereignty, authority, earning one's livelihood, trades, and sciences. It serves as prolegomena to the study of history, in which Ibn Khaldun developed the concepts for comprehending human civilization. Second part is related to history of the Arabs, their generations and dynasties from the human creation to the author's time. It contains accounts of some of the contemporary nations and great men and their dynasties. Third part deals with the history of the Berbers and tribes appertaining to them and their kingdoms and dynasties in North Africa.

2 For details of the episode, see, Walter J. Fischel, Ibn Khaldun and Tamerlane (Berkley: University of California Press, 1952)

3 Details of his career are known primarily through his autobiography, Al-Tarif which is the concluding part of his history. Different works have extracted his biographical details from this autobiography and a few scattered sources. See, Nathaniel Schmidt, Ibn Khaldun: Historian, Sociologist and Philosopher (Lahore: Universal Books, n.d.), 34-38; M.A. Enan, Ibn Khaldun: His Life and Works (New Delhi, Kitabbhavan, 2000 [1932]); Charles Issawi, An Arab Philosophy of History: Selections from the Prolegomena of Ibn Khaldun of Tunis (1332-1406) (London: John Murray, 1958), 1-6.

4 Encyclopedia of Islam, III: 825, s.v. "Ibn Khaldun"

5 Schmidt, Ibn Khaldun, 42.

6 Issawi, Arab Philosophy of History, 3.

7 The full title is: Kitab al-Ibar, wa Diwan al-Mubtada wal Khabar, fi Ayyam al-Arabi wal Ajami wal Barbar, wa man Asrahum min zawi al-Sultan al-Akbar (A book of instructive examples, and a collection relating to the subject and the attribute, in the days of the Arabs, the Persians, and the Berbers and the great rulers who were their contemporaries). 
His Muqaddimah is commonly regarded as one of the most significant works of medieval Muslim civilization. The noted historian, Arnold Toynbee, appreciating the scope and scale of Ibn Khaldun's work, has called it "undoubtedly the greatest work of its kind that has ever yet been created by any mind in any time or place." ${ }^{8}$ Ibn Khaldun was concerned with the history of civilization (al-umran) in all its complexity, and Muqaddimah encompasses its social, economic, and natural, as well as political and religious aspects. He is, therefore, labeled by some modern scholars as a founder of "scientific history," as well as of sociology. A major theme of Muqaddimah is the rise and fall of states, or dynasties. States, as explained by Ibn Khaldun, rose and fell in a cycle similar to human life: birth, maturity, decline, and death. Central to Ibn Khaldun's discussion of the life cycles of states is the concept of asabiyah, variously translated as solidarity, group feeling, or group consciousness. A group with strong asabiyah (established through means such as blood relation or religious solidarity, etc.) would be able to achieve supremacy over other groups and establish a state. However, once predominance was achieved, asabiyah would eventually fade, leading to the overthrow of political power and the establishment of a new state.

Ibn Khaldun's views were shaped in part by the events he witnessed in his own life. However, his life, not just his socio-historical analysis, has an importance which goes beyond his own age. As mentioned by a prominent Muslim anthropologist, Ibn Khaldun's life forms a bridge, a transition, between the distinct phases of Muslim history...the Arab dynasties in the tail-end of which - as in Umayyad Spain - he lived, and the great Muslim empires which would develop by the end of the century in which he died. His life also teaches us many things, confirming them for us in our own period: the uncertainty of politics; the fickleness of rulers; the abrupt changes of fortune, in jail one day, honored the next; and finally, the supremacy of the ideal in the constant, unceasing, search for ilm, knowledge, and therefore the ultimate triumph of the human will and intellect against all odds. ${ }^{9}$

Ibn Khaldun's active political life remained confined to North Africa and Spain. In the thirteenth and fourteenth centuries, these areas showed serious symptoms of general decline and disintegration. This is corroborated by the accounts of Ibn Khaldun himself and by other contemporary sources. Western North Africa, where Ibn Khaldun grew up and spent fifty years of his life before going to Egypt, was "a spectacle of chaos and desolation." ${ }^{10}$ Constant struggle with Berber tribes in the south and rising Christian powers in the north resulted in frequent political upheavals and changes in the fortunes of ruling dynasties. It became a constant feature of political culture of the region and prevented the establishment of stable political institutions and traditions. Though Muslim civilization in other parts was in the process of decline, in the words of Muhsin Mahdi, "in North Africa it had virtually ceased to exist."

8 Cited in Bruce B. Lawrence, "Introduction," in The Muqaddimah: An Introduction to History, tr. by Franz Rosenthal, abridged and edited by N.J. Dawood (Princeton: Princeton University Press, 2005), viii. All other references of the Muqaddimah have been given from the same abridged edition.

9 Akbar S. Ahmed, Islam: Making Sense of Muslim History and Society (London: Routledge, 1988), 106.

${ }^{10}$ Muhsin Mahdi, Ibn Khaldun 's Philosophy of History: A Study in the Philosophic Foundation of the Science of Culture (Chicago: The University of Chicago Press, 1957), 26; See also for a detailed study of various aspects of medieval North African society, Michael Brett, Ibn Khaldun and the Medieval Maghrib (Aldershot: Ashgate, 1999)

11 Mahdi, Ibn Khaldun's Philosophy of History, 26. 
Ibn Khaldun grew up in that same decadent society and became a part of that political culture. His social analysis rested mainly on his own experiences of that society. One of the major motives for compiling his socio-historical work was to make an attempt to understand the nature and causes of the decline and chaotic conditions prevailing in the Islamic world, particularly in North Africa, and to draw some lessons about the nature of human history and society. That is perhaps the reason that he has called his universal history as Kitab-ul-Ibar. Muhsin Mahdi has perceptively remarked that:

\begin{abstract}
The key word in the title of Ibn Khaldun's work which seems to contain some hints and allusions is not 'history' (tarikh or khabar), but the word ibar; for the work is first and foremost called 'The Book of the Ibar. . . . we might simply choose a less significant aspect of its meaning and translate it as 'instructive examples.' . . . It was in relation to history, however, that ibra was most commonly used in the Koran and in the Traditions of the Prophet. Man was urged to 'consider' the past as the evidence, allusions, and examples, through which he could pass from the appearance of things to the knowledge of the unseen. . . The use of ibra [by Ibn Khaldun] in connection with history indicated essentially the activity of looking for the unity of the plan underlying the multiplicity of events, of grasping the permanence pervading their everchanging and destructible character, and of using the results of such reflections in the management of practical affairs. ${ }^{12}$
\end{abstract}

As Ibn Khaldun himself wrote that "the past and the future are more similar to each other than water is to water." ${ }^{13} \mathrm{We}$ can get some useful insights from the observations of Ibn Khaldun contained in his Muqaddimah and apply them to the present crisis of Muslim civilization. Though it should be conceded that all his observations are certainly not applicable to the modern world, yet the scholars generally agree that notwithstanding the lapse of centuries, he still maintains "its value, vigour and modernity, and occupies a high place among the monuments of world thought." 14 The list of his observations can be extended to many other quarters, but for the present purpose, four main areas have been selected for further exposition. These include Ibn Khaldun's analysis of power and the state, his idea of leadership, his concept of asabiya, and his emphasis on ilm [knowledge].

\title{
ANALYSIS OF POWER AND THE STATE
}

State and its political institutions occupy the central stage in Ibn Khaldun's analysis of civilization and society. Building of cities and extent of urbanization are dependent on the support and protection of a powerful state. The state is the cause of the development and organization of economic institutions: it is the greatest of buyers, the greatest spender of money, and the largest monopoly; and economic luxury is dependent on the protection and policies of the state. Finally, the state is the cause of the flourishing of the sciences, directly through its support of scientific institutions and indirectly as the cause of the other aspects of civilization in the absence of which the sciences could not exist. The life of the state and the life of the civilization it brings into existence are coextensive. A civilization follows the rise of a powerful state, it is limited in space by the extent of the state, it flourishes when the state is at the height of its power, and it disintegrates with the state's disintegration. Consequently, Ibn Khaldun's study of the

${ }^{12}$ Ibid., 26, 38, 64-68.

13 Ibid., 149 .

${ }^{14}$ M.A. Enan, Ibn Khaldun: His Life and Works (New Delhi, Kitabbhavan, 2000 [1932]), v. 
development of civilization is primarily a study of the development of the civilized state and an examination of the interaction of the other aspects of civilization within the state. The problems of the creation of the state, the stages through which it passes, its various forms, and the causes of its decline, are the central problems of Ibn Khaldun's socio-historical analysis. ${ }^{15} \mathrm{He}$ has tried to demonstrate in the History the workings of siyasa [political power], its functions and limits. ${ }^{16}$ One of the most striking features in Ibn Khaldun's theory of power and its consequences which distinguish him from earlier political thinkers was his awareness of larger and more impersonal forces shaping the political process. ${ }^{17}$

In the post-colonial period, Islam has broadly been interpreted in three ways. These have generally been recognized as Modernist, Revivalist ${ }^{18}$ and Traditional approaches. Modernist approach for its exponents has such figures as Ziya Gokalp and Mustafa Kamal in Turkey, Muhammad Abduh in Egypt and Sir Syed Ahmad Khan in South Asia. Revivalist approach has been expounded by Syed Qutub and Ikhwan-ul-Muslimun in the Middle East and Abul Ala Maududi and Jamat-i-Islami in South Asia. ${ }^{19}$ Traditional approach is related to traditional Sufi orders throughout the Muslim world and particularly Deoband School of thought in South Asia. In the modern period, it has been forcefully expounded by Sayyed Hossein Nasr. ${ }^{20}$ All the three schools of thought, with varied emphasis, have grappled with the problem of defining Islamic modes of power and using diverse ways and means of establishing an Islamic state in the modern world. A particularly crucial issue in the post-colonial Muslim societies was to devise and work within or without the political systems imposed by the colonial powers, roughly modelled on Western lines. As Western political systems evolved through a period of centuries within the intellectual framework of the West which was steeped in opposition to Christianity, particularly to the authority of the Church, this Western political discourse rested on the negation of any metaphysical reality, over-emphasis on role of the human being, human will and rationality and, consequently, nearly unrestrained notion of individual freedom and liberty. The modernist approach to Islam which emerged in the last half of the nineteenth century in reaction to Western colonialism and emphasised reconciliation between Islam and the West, naturally accepts Western political systems with only minor variations. It does not intellectually challenge the Western democratic institutions, but rather accepts, sometimes with minor variations, as a developed political system. On the other hand, the traditional approach, being influenced by the medieval notions of statecraft and political conditions of the prevalence of hereditary kingship, only marginally recognized the importance of political power and laid more emphasis on individual piety and reformation of the self. Its dominant exponents still consider politics as playing only a minor part in Muslim civilization and if some enter the political arena, they do so with considerable reluctance. In contrast to these two approaches, the Revivalists have attempted to evolve an alternate political system and have directly confronted the Western political discourse; thus, asserting the necessity of Islamising the political culture of Muslim

${ }_{15}$ Mahdi, Ibn Khaldun 's Philosophy of History, 204.

${ }_{16}$ Tarif Khalidi, Arabic Historical Thought in the Classical Period (Cambridge: Cambridge University Press, 1994), 224.

${ }^{17}$ Ibid., 225. For a comparative study of Ibn Khaldun's political ideas with other Muslim philosophers, see Enan, Ibn Khaldun, 121-133.

${ }^{18}$ It has also been variously referred to as Islamist and Fundamentalist.

19 S.V.R. Nasr, The Vanguard of the Islamic Revolution: The Jama 'at-i Islami of Pakistan (Berkeley: University of California Press, 1994); idem, Mawdudi and the Making of Islamic Revivalism (New York: Oxford University Press, 1996)

${ }^{20}$ See Nasr's Traditional Islam in the Modern World (London: Kegan Paul International, 1987), especially "Prologue: What is Traditional Islam," 11-25. 
societies and consequently the state. ${ }^{21}$ As Abul Ala Mawdudi, one of the most important ideologues of Islamic revival, explained:

the struggle for obtaining control over the organs of the state, when motivated by the urge to establish the din [religion as complete code of life] and the Islamic Shariah and to enforce the Islamic injunctions, is not only permissible but is positively desirable and as such obligatory. ${ }^{22}$

However, this centrality of politics and the state in the Islamic discourse, championed by the Revivalists, has evoked biting criticism and strong opposition from the other two Muslim groups, Modernists as well as Traditionalists. Maulana Taqi Usman, one of the exponents of traditional Islam, voices his concerns in the following words:

In their zeal to refute secularism, some writers and thinkers of the present age have gone so far as to characterize politics and government as the true objective of Islam, the reason why the prophets were sent [by God to the people], indeed the very reason for the creation of the human being. And they have not only given other Islamic commandments - for instance on matters of worship - a secondary position, but have even deemed them to be mere means for political ends, just a way of training people [towards political mobilization]. ${ }^{23}$

This kind of criticism has led to diluting the influence of the Revivalists and has created rifts between the three groups.

Ibn Khaldun makes it unequivocally apparent that an Islamic state should be the desired goal. He makes a distinction between siyasa diniya - based on God's revealed law, the Sharia - and siyasa aqliya - based on political laws made by rational man. Ibn Khaldun leaves no doubt that the law of the prophetic lawgiver is best and is superior to that of the human lawgiver, who is guided only by his own reason. ${ }^{24}$ According to Ibn Khaldun, "the state whose law is based upon rational government and its principles, without the authority of the Shariah, is likewise blameworthy, since it is the product of speculation without the light of God ... and the principles of rational government aim solely at worldly interests." Caliphate is the only perfect state, which is based on the true practice of the Shariah, and which furthers both the temporal and spiritual interests of its subjects. ${ }^{25}$

Ibn Khaldun's observation is very much clear. There is no doing away with politics, particularly in the modern world, where the role of the state has been extended beyond any bounds. Without Islamising the State, Muslim civilization cannot prosper. The Modernists have to recognise the irreconcilability of Islam with Western political discourse while the Traditionalists should give politics the central place in their view of Islam and one of the important means to reform Muslim societies. On the other hand, the Revivalists must strive to preserve the ethical dimension of politics, by not succumbing to the temptations of power, and do their utmost not to dilute the religious colour.

${ }^{21}$ For a discussion of the relationship of Islam and modern state, see, Abdelilah Belkeziz, The State in Contemporary Islamic Thought: A Historical Survey of the Major Muslim Political Thinkers of the Modern Era (London: I.B. Tauris, 2009), and John L. Esposito and James P. Piscatori, “Democratization and Islam," Middle East Journal, 45, No. 3 (Summer, 1991): 427-440.

${ }^{22}$ Cited in M. Qasim Zaman, Maulana Ashraf Ali Thanawi: Makers of the Muslim World (Oxford: Oneworld, 2007), 117.

${ }^{23}$ Cited in Ibid., 116-17.

${ }^{24}$ E.I.J. Rosenthal, Political Thought in Medieval Islam: An Introductory Outline (Cambridge: University Press, 1962), 95.

${ }^{25}$ H. A. R. Gibb, "The Islamic Background of Ibn Khaldun's Political Theory" Bulletin of the School of Oriental Studies, University of London, Vol. 7, No. 1 (1933): 30 


\section{IDEAS ON LEADERSHIP}

Another dominant idea in Ibn Khaldun's socio-historical analysis of society is the importance of the ruler and his duties to the ruled. The leader, according to him, embodies both political and moral authority. ${ }^{26}$ Ibn Khaldun believes that such a Muslim leader (Caliph) must have four qualifications. First, he must have knowledge ( $\mathrm{ilm}$ ) of the Law and be proficient in that knowledge to the extent of being able to interpret personally and elaborate on the Law (ijtihad). Second, he must be just. Justice (adala) in this context includes both general and particular justice: the Caliph must be good or righteous as well as just in distributing offices and insuring that they dispense justice among the members of the community. Thirdly, the Caliph must have competence (kifaya): he must be courageous in applying the Law. He must have courage in waging wars, know how to conduct them, and be able to arouse people to fight them. He must know the nature of solidarity; and must be shrewd, resourceful, and forceful in conducting the affairs of the state. It is primarily this quality of competence which Ibn Khaldun emphasizes as leading to the protection of religion, the establishment of state, and the management of public interests. Finally, he must be free from bodily and mental defects, and of circumstances that may prevent him from the exercise of his powers. ${ }^{27}$

Ibn Khaldun devotes a chapter to the relationship between the ruler and the ruled which has the revealing title: "Exaggerated severity harms and mostly ruins the state (mulk)." The welfare of the subjects and of the state rests on good relations between the ruler and his subjects. The essence of the ruler is that he cares for their affairs. Kindness towards the subjects is an essential quality of the ruler. Kindliness and good treatment also consist in caring for their livelihood. According to Ibn Khaldun, overriding consideration for the ruler should be public welfare and the interests of the state. ${ }^{28}$

In the present circumstances, one of the major crises that faces Muslim society is that of leadership. Apparently, there are different categories of leaders in the Muslim world: kings, military dictators, so-called democrats and, tribal men or religious scholars. However, it is difficult to point out a leader who also enjoys a widespread moral authority and fulfils the four conditions laid down by Ibn Khaldun. This crisis of leadership is both a symptom as well as a cause of the breakdown of Muslim civilization.

\section{CONCEPT OF ASABIYAH}

Asabiyah is one of the most known terms of Ibn Khaldun. It has been variously rendered into English as social solidarity, social cohesion, group feeling, etc. The concept of asabiyah is at the core of his whole socio-historical analysis. He has formulated the concept of asabiyah as a type of group solidarity based on blood or strong bond of mutual affections among the members of the group, which make them willing to fight and die for one another. ${ }^{29}$ The basis of solidarity may be a common language, culture, and code of behaviour at different levels of organisation such as

${ }^{26}$ Akbar S. Ahmed relates Ibn Khaldun's science of culture with the science of good governance. See his article, "Ibn Khaldun's Understanding of Civilizations," 29.

27 Muqaddimah, 158-59. Ibn Khaldun has also discussed the condition of Quraishiyat for being a Caliph but has not accepted it.

28 Rosenthal, Political Thought in Medieval Islam, 93.

${ }^{29}$ Mansoor Moaddel, "The Study of Islamic Culture and Politics: An Overview and Assessment," Annual Review of Sociology, 28 (2002): 368. 
family, clan, tribe, and kingdom or nation. With asabiyah, society fulfills its primary purpose to function with integrity and transmits its values and ideas to the next generation. ${ }^{30}$ Ibn Khaldun points out that it is asabiyah which is the force working behind every civilization. If asabiyah is strong, the tribe will be able to develop a civilization and retain its dominant position. As asabiyah fades away, civilization begins to collapse and ultimately is replaced with a civilization with stronger asabiyah. ${ }^{31}$

In the present day Muslim world, every one is witnessing that Muslim societies are breaking down. There are serious political fissures and socio-cultural dissentions which are sapping the vitality of the Muslim societies. The process started with the advent of European colonialism. In the beginning, this phase of European colonialism which spread throughout the Muslim lands in the eighteenth century was nothing more than a political dominance which exposed the frigidity of political institutions of Muslim empires and states. However, as colonialism spread its tentacles, it led to cultural and intellectual dominance, resulting in the virtual collapse and extirpation of traditional institutions and structures. Colonial masters changed the language of the Muslim lands, replacing them with European languages as the administrative language, thus severing the connection of the new generation of Muslims in these colonized lands with their literary and cultural traditions of more than thousand years. The old educational system was crushed and the institutions were forced to close down. In their place, the European powers introduced a new system of education, the basic purpose of which was to impress upon the intellectual hegemony of the West and to produce an educated class which was imbued with Western values and traditions. ${ }^{32}$ The colonial powers imposed an administrative and political structure which was alien to the people of the land and naturally the latter had no emotional attachment with it. Thus Franz Fanon argues that:

Colonialism is not satisfied merely with holding a people in its grip and emptying the native's brain of all form and content. By a kind of perverted logic, it turns to the past of the oppressed people, and distorts, disfigures, and destroys it. This work of devaluing pre-colonial history takes on a dialectical significance today. ${ }^{33}$

This destruction of their past has made the Muslim masses lose much that was extremely valuable. Muslim scholars have pointed out a number of reasons for this loss such as massive urbanization, dramatic demographic changes, population explosion, large-scale migrations to the West, the gap between rich and poor, the wide spread corruption and mismanagement of rulers, rampant materialism, the crisis of identity and, new and often alien ideas communicated from the West which challenge our classical values and customs. ${ }^{34}$ The reality is that all these are the symptoms of the breakdown of asabiyah. The real cause lies in the fundamental break from the past which the colonial powers effected in all the Muslim societies. Ibn Khaldun himself hinted towards it when he wrote that those who are conquered and enslaved, wither away, since to be enslaved is

${ }^{30}$ Ahmed "Ibn Khaldun's Understanding of Civilizations," 30.

31 Muqaddimah, Ch. 3.

32 Thomas Macaulay advocated the production of a specific kind of educated subjects in India: 'We must at present do our best to form a class who may be interpreters between us and the millions we govern: a class of persons, Indian in blood and colour, but English in taste, in opinions, in morals, in intellect.' "Minute on Indian Education" in Postcolonial Studies Reader, eds. Bill Ashcrof, Gareth Grifiths and Helen Tiffin (London: Routledge, 1995), 430.

${ }^{33}$ Franz Fanon, Wretched of the Earth, tr. Constance Farrington (New York: Grove Press, 1963).

34 Ahmed "Ibn Khaldun's Understanding of Civilizations," 3. 
contrary to human nature and leads to the loss of hope. ${ }^{35}$ If the Muslim societies want to gain asabiyah and establish social cohesion and solidarity, they should do away with colonial legacy and reconnect themselves with their forgotten past.

\section{EMPHASIS ON ILM (KNOWLEDGE)}

Ibn Khaldun gives an important place to Ilm and devotes chapter six of the Muqaddimah to different forms of sciences. ${ }^{36} \mathrm{He}$ establishes a direct relationship with development of sciences and growth of civilization. He writes that "the institution of scientific instruction has disappeared among the inhabitants of Spain. Their former concern with the sciences is gone, because Muslim civilization in Spain has been decreasing for hundreds of years. . . O O the intellectual disciplines, not even a shadow remains. The only reason for that is that the tradition of scientific instruction has deteriorated and the enemy has gained control over most of it." ${ }^{37}$ However, he also believes that sciences flourish only after the necessities of life have been provided. He thinks that "the degree of their advance is dependent on the fulfilment of certain conditions: the possibility of leisure, the continuity of a civilized tradition, the social demand for the services of the learned, and the appreciation and encouragement of the rulers of their profession as expressed in their generosity in establishing schools and founding endowments to maintain them." ${ }^{\text {}}$

Muslims in their heydays developed a strong tradition of knowledge. Muslim culture was basically a book culture and it has been estimated that during the period from the beginning of Islam to the fourteenth century AD, 900,000 books of only Arabic language were compiled. ${ }^{39}$ The knowledge generated by the Muslims, though diverse and pluralistic, was invariably consistent with their own Islamic worldview. Ibn Khaldun though studied and wrote on history, philosophy and other social sciences. He, like most other medieval Muslim scholars, has reconciled the rational sciences with religious knowledge. He believes that the highest and most important source of knowledge is the knowledge that comes from the prophets. ${ }^{40}$ When some of the Western scholars portrayed Ibn Khaldun as a liberal scholar who challenged the norms of Islamic law on the basis of rational thought, H.A.R. Gibb wrote:

Ibn Khaldun was not only a Muslim, but as almost every page of the Muqaddima bears witness, a Muslim jurist and theologian, of the strict Maliki school. For him religion was far and away the most important thing in life-we have seen that he expressly calls his study a thing of subsidiary value-and the Shariah the only true guide. ${ }^{41}$

${ }^{35}$ Cited in Mahdi, Ibn Khaldun 's Philosophy of History, 178.

${ }^{36}$ For a detailed exposition of this chapter, see Zaid Ahmad, Epistemology of Ibn Khaldun (London: Routledge Curzon, 2003).

37 The Muqaddimah, 341.

${ }^{38}$ Mahdi, Ibn Khaldun 's Philosophy of History, 222.

39 Aziz al-Azmeh, Arabic Thought and Islamic Societies (London: Croom Helm, 1986), i; For a brief view of the encyclopaedic nature of Muslim scholarship, see, Gerhard Endress, Organizing Knowledge: Encylopaedic Activities in the Pre-Eighteenth Century Islamic World (Brill: Leiden, 2006).

${ }^{40}$ Ahmad, Epistemology of Ibn Khaldun, 24-25.

${ }^{41}$ Gibb, "Islamic Background of Ibn Khaldun's Political Theory," 28. Allama Muhammad Iqbal has also written: "The truth is that the whole spirit of the 'Prolegomena' of Ibn Khaldun appears to have been mainly due to the inspiration which the author must have received from the Quran." The Reconstruction of Religious Thought in Islam, ed and ann. Saeed Sheikh, $3^{\text {rd }}$ ed. (Lahore: Institute of Islamic Culture, 1996), 111. 
In stark contrast to their medieval traditions, in the modern world, the Muslims have lagged behind in the field of knowledge. Their universities and research centres occupy the least importance in the academic world and they have failed to make their mark in the scientific field. One of the reasons is the colonisation of Muslim lands in the eighteenth and nineteenth centuries. The present day modern educational institutions were established during the colonial period and were implanted by the colonial powers. This fact has practically alienated the Muslim masses who do not feel emotionally attached to Western style educational institutions. The kind of knowledge which is taught in these institutions is steeped in Western epistemological tradition. There is a growing realization in the Muslim world that modern knowledge has grown out of western intellectual tradition and represents a particular worldview. The Westernised knowledge is in many ways alien to Muslim mindset and irreconcilable to Islamic traditions. Three issues can particularly be highlighted in this regard. The first and foremost is the worldview which developed in the post-Renaissance Europe. It drastically transformed man's conceptions about God, nature and the universe. Based on the denial of any metaphysical reality, a new paradigm of knowledge was created on which the edifice of modern knowledge, particularly of social and behavioural sciences, was constructed. Secondly, modern knowledge developed in the West is materialistic and utilitarian, devoid of any ethical value. Thirdly, modern knowledge is essentially Eurocentric, which devalues, if not altogether denies, the contribution of other cultures and civilizations. These three aspects succinctly highlight the difference between Western and Islamic view of knowledge.

Thus, it is very much obvious that Muslim societies cannot progress in education and learning unless modern knowledge is not only 'de-westernised' but is also Islamised. Muhammad Naquib Al-Attas has written that the greatest challenge for Muslim civilization today is the challenge of knowledge, because it is the knowledge as "conceived and disseminated throughout the world by Western civilization." ${ }^{42}$ Various institutions are working to face this challenge and many attempts have been made to Islamize knowledge. However, a large part of Muslim intelligentsia and academic fraternity has remained indifferent, if not altogether hostile, to such endeavours. The need is to create more awareness about the issue and to develop coordination among different institutions.

\section{CONCLUSION}

Seven centuries have passed between the times of Ibn Khaldun and the contemporary world but some of his ideas seem to be as fresh as ever. Muslim civilization is facing some of the severest challenges of its lifetime and Ibn Khaldun's solution lay in multi-pronged strategy: invigorating an alternate political discourse based on the Islamic injunctions and making state and politics the basis of transforming the Muslim society; creating a leadership which also enjoys a moral authority and possesses the qualities of ilm (knowledge), adl (justice), kifaya (competence) and is seriously concerned to mitigate the sufferings of the people; developing an asabiyah (social cohesion) which has been weakened by colonial powers' deliberate attempts to distort past Muslim history and to create linguistic, cultural and ethnic divisions in the Muslim world; and finally, reconstructing the medieval Muslim legacy of knowledge and learning which challenges the westernisation of knowledge and attempts to de-westernise as well as Islamise it.

42 Syed Muhammad Naquib Al-Attas, Islam and Secularism (Lahore: Suhail Academy, 1998 [1978]), 133. For the whole discussion on de-westernization of knowledge, see 133-68. 


\section{SELECTED BIBLIOGRAPHY}

1. Ahmad, Zaid. Epistemology of Ibn-e-Khaldun. London: Routledge Curzon, 2003.

2. Ahmed, Akbar S. Islam: Making Sense of Muslim History and Society. London: Routledge, 1988.

3. Ahmed, Akbar. "Ibn-e-Khaldun's Understanding of Civilizations and the Dilemmas of Islam and the West Today." In Middle East Journal, 56, No. 1(Winter, 2002)

4. al-Attas, Syed Muhammad Naquib. Islam and Secularism.Lahore: Suhail Academy, 1998 [1978].

5. al-Azmeh, Aziz. Arabic Thought and Islamic Societies. London: Croom Helm, 1986

6. Belkeziz, Abdelilah. The State in Contemporary Islamic Thought: A Historical Survey of the Major Muslim Political Thinkers of the Modern Era. London: I.B. Tauris, 2009.

7. Brett, Michael. Ibn-e-Khaldun and the Medieval Maghrib. Aldershot: Ashgate, 1999.

8. Enan, M.A. Ibn-e-Khaldun: His Life and Works. New Delhi, Kitabbhavan, 2000 [1932].

9. Endress, Gerhard. Organizing Knowledge: Encylopaedic Activities in the Pre-Eighteenth Century Islamic World. Brill: Leiden, 2006.

10. Esposito, John L. and James P. Piscatori, "Democratization and Islam." In Middle East Journal, 45, No. 3 (Summer, 1991): 427-440.

11. Fanon, Franz. Wretched of the Earth, tr. Constance Farrington. New York: Grove Press, 1963.

12. Fischel,Walter J. Ibn-e-Khaldun and Tamerlane. Berkley: University of California Press, 1952.

13. Gibb, H. A. R. "The Islamic Background of Ibn-e-Khaldun's Political Theory." InBulletin of the School of Oriental Studies, University of London, Vol. 7, No. 1 (1933): 30

14. Iqbal, Muhammad. The Reconstruction of Religious Thought in Islam, ed and ann. Saeed Sheikh, $3^{\text {rd }}$ ed. Lahore: Institute of Islamic Culture, 1996.

15. Issawi, Charles. An Arab Philosophy of History: Selections from the Prolegomena of IbnKhaldun of Tunis (1332-1406). London: John Murray, 1958.

16. Khalidi,Tarif. Arabic Historical Thought in the Classical Period. Cambridge: Cambridge University Press, 1994.

17. Lawrence, Bruce B. "Introduction." In The Muqaddimah: An Introduction to History, tr. by Franz Rosenthal, abridged and edited by N.J. Dawood. Princeton: Princeton University Press, 2005.

18. Macaulay, Thomas. "Minute on Indian Education." In Postcolonial Studies Reader, eds. Bill Ashcrof, Gareth Grifiths and Helen Tiffin. London: Routledge, 1995.

19. Mahdi, Muhsin. Ibn Khaldun 's Philosophy of History: A Study in the Philosophic Foundation of the Science of Culture. Chicago: The University of Chicago Press, 1957. 
20. Moaddel, Mansoor. "The Study of Islamic Culture and Politics: An Overview and Assessment.'In Annual Review of Sociology, 28 (2002): 368.

21. Nasr, Hossein.Traditional Islam in the Modern World.London: Kegan Paul International, 1987.

22. Nasr, S.V. R. The Vanguard of the Islamic Revolution: The Jama 'at-ilslami of Pakistan. Berkeley: University of California Press, 1994.

23. Nasr, S.V.R. Mawdudi and the Making of Islamic Revivalism. New York: Oxford University Press, 1996.

24. Rosenthal, E. I. J. Political Thought in Medieval Islam: An Introductory Outline. Cambridge: University Press, 1962.

25. Schmidt, Nathaniel. Ibn-e-Khaldun: Historian, Sociologist and Philosopher. Lahore: Universal Books, n.d.

26. Zaman, M. Qasim. Maulana Ashraf Ali Thanawi: Makers of the Muslim World. Oxford: Oneworld, 2007.

Encyclopedia of Islam, III: 825, s.v. "IbnKhaldun" 